\title{
An Alternative Business Models for Suvarnabhumi Airport Rail Link (SARL) Project
}

\author{
Tin Chaingam ${ }^{1, *}$, Sahanon Tungbenchasirikul ${ }^{2}$ \\ ${ }^{1}$ Independent Consultant and DBA candidate, Naresuan University, Thailand \\ ${ }^{2}$ Bangkok Campus, Naresuan University, Thailand
}

Copyright $\mathrm{O} 2016$ by authors, all rights reserved. Authors agree that this article remains permanently open access under the terms of the Creative Commons Attribution License 4.0 International License

\begin{abstract}
To compare and evaluate alternative model, in order to determine the suitable management for presenting an efficiency selection to administrator, the scope of research focused on the operations and feasibility study of the Suvarnabhumi Airport Rail Link (SARL) project. The results showed that the only business models with potential were by being a subsidiary company under the State Railway of Thailand (SRT). Further, the feasibility study was conducted and found that both of business models which are business unit and subsidiary had the same payback (PB) period of 12 years and 4 months but the return on investment (ROI) of the subsidiary company was better as shown the summarizing table in appendix. It is suggested to apply the strategic management with efficiency and effectiveness to improve the service quality and the image of the organization. Further study should focus on exploring an economic impact of the project that benefits the economy and society. The effects of those may bring returns to the society or country other than only Suvarnabhumi Airport Rail Link (SARL) itself.
\end{abstract}

Keywords Infrastructure Development, Railway Transportation

\section{Introduction}

From the past, Thailand has continued to develop its infrastructure by setting up policies and strategies then stipulated them in the National Economic and Social Development Plan 9 [1]. The Government of Thailand has also seen the importance of this issue. In order to rely less on car usage and reduce fuel use, we have shifted our attention to developing rail transport infrastructure with new innovations such as electricity powered rail system that could reduce petroleum imports from overseas, increase competitiveness, increase productivity and enhance the service sectors of the country. Moreover, it can also help reduce air pollution and protect the environment for the country.

In addition to this, the researchers have compared the extent and evaluated business management models to determine for the right business model and present to management of Suvarnabhumi Airport Rail Link (SARL) in order to survive and be effective after operation since 2010 .

\section{Materials and Methods}

\subsection{Definitions of Terms}

State Railway of Thailand (SRT), Business Unit (BU). The business unit is a part of the SRT but its account receivable and payable is separated from the SRT.

State Railway of Thailand (SRT), Subsidiary Company. For an establishment of an SRT's subsidiary which the government owns 100 percent of the shares, the company is regarded as a private company. The company can have its own work regulations and own administration of the SARL project.

State Railway of Thailand (SRT), Outsourcing SRT must pay the fee to an outside company. The outsourcing cost and term must be the most benefit to SRT if experienced outsourcing company is selected.

State Railway of Thailand (SRT), Concessionary. The concept is similar to outsourcing but the concessionaire shall pay the fee to the SRT as mentioned in the agreement.

\subsection{Business Model Generation}

Business model generation was classified as follows [2]

Customer Segments, The philosophy that the customer voice is the voice of heaven was taken as its concept. Products and services offered were analyzed to serve the diversified target customers. Train services in each direction and each line have several target groups as customers. The service provider may be determining the target groups.

Value Propositions, Organization seeks solutions to 
respond to customer needs by offering value. Value is a key reason that customers choose one company rather than another company. It can help solve customer problems or responding to customer demand. It is a value proposition that respond to the need of customers.

Cost Leader Strategy, It is the philosophy to see what is needed to be done or is there other method that will cause a reduction in the cost of doing business and production cost without sacrificing the quality of its products and services. The users would also receive lower cost of consumption and services as well as a discount on the use of public transport.

Channels. Organization can offer business value then sent to the customers via products and services communication and via direct and related business in various formats to increase revenue and place importance on coordination with the customer.

Customer Relationship Management (CRM). Companies should clearly identify the patterns of relationship that it wants to establish with each group of customer. The relationship may be a private or automatic one. Customer relationship may be driven by motivation such as customer finding, customer retention and increase customer to increase sales.

Revenue Streams, This is the result of a successful value proposition, which is the heart of the business model. Revenue streams are like blood vessel. Each income stream may have different pricing mechanisms such as fixed pricing, price bargain, auctions, market-oriented pricing, volume pricing and yield management pricing.

Key Resources, Key resources are the primary resources that are the factors of business operation. Readiness of the main resources is what used to offer and deliver to other components that we mentioned before. Every business model relies on primary resources, which enables companies to build and offer values, to access to the markets, to maintain relationships with customers, and to create revenue.

Key Activities are the most important elements that companies need to execute in order to bring the business model to success. Every business model must comprise of a set of key activities as part of the management activity similar to the key resources. The key activities will vary depending on the type of the business model. For example, key activities of a software vendor such as Microsoft are to create software programs.

Key Partners, Some activities were sent out to be executed by outside parties and some resources were sent in from outside the companies. Partnerships were built by a variety of reasons and the alliance has become a key element for many business models.

Cost Structure, Components of business models have resulted in creating significant costs. Creation and delivery of value, maintaining client relationships, and revenue generation are associated with costs. These costs can be calculated quite easily after the key resources, key activities, and key partners were determined.

Regulations are laws that associated with the business. In order to do a business, both domestic and international, laws and regulations including social, tradition and culture of the country must be studied. Learning and awareness on this issue is an important factor that companies will have to study.

2.2.12 Business Organization Risk model [3]. There are 7 types of risks as follow:

(1) Credit Risk is most simply defined as the potential that a bank borrower or counterparty will fail to meet its obligations in accordance with agreed terms.

(2) Liquidity Risk / Financial Risk such as the lack of liquidity in the business, occurrence of non-performing loan (NPL) and possession of non-performing asset (NPA).

(3) Operation risk. Erroneous or negligence business execution and operation is also a risk that may lead to damages.

(4) Marketing Risk. A trading business dealing with foreign enterprises would face currency exchange rate risk and inflation Rate. Also, there is a risk of materials or raw materials shortage and price elevation.

(5) Country/political risk such as political instability, coup d'état, our seizure of state power could result in damages.

(6) Strategic Risk is a risk from the management of business.

(7) Compliance risk is the risk associating to complying with contracts, laws, and regulations. It may lead to disputes and lawsuits that may cause damages.

\section{An Alternative Business Model}

In this study, the researcher shall review the four business models [5] previously and review the business model currently being conducted in order to analyze to see in which model the Suvarnabhumi Airport Rail Link should be managed. The four business models are as follow:

\section{SRT Business Unit- BUs}

The business unit is a part of the SRT but its account receivable and payable is separated from the SRT. SRT executives shall responsible for fare pricing, operation, management, and financial matters of the project. The advantages of being a business unit in the SRT is that borrowing costs will be lower because the SRT, which is a state enterprise, and the government is the supporters. However, operation and business decision will be hard and slow because everything must be incompliance with bureaucratic regulations even fare pricing, which affects income of the organization. SRT has a lot of debts and constant expenses; for example, salaries of employees and executives, etc. Therefore, the repayment of long-term debt is difficult and there will be a lack of money to improve and maintain of the rail system that is a long-term demand. These factors will reduce the efficiency of the Airport Rail Link project.

2. SRT's subsidiary with the government as the sole shareholder. 
For an establishment of an SRT's subsidiary which the government owns 100 percent of the shares, the company is regarded as a private company. The company can have its own work regulations and own administration of the Airport Rail Link project. However, it still has to be under the regulations of the SRT and the government so it is more professional. The company can develop into a center of excellence Rail Company with more transparency.

\section{SRT's Outsourcing}

In outsourcing to an outside company, the outsourcing cost and term must be properly considered and must provide the most benefit to the SRT. If an experienced outsourcing agency is selected, it company shall be flexible with good business culture. However, the disadvantage is that SRT will have no bargaining power because if the outsourced company knows that it is the only company capable of executing the operation, the outsourcing cost will be high and would defer the defect warranty to the construction contractor. Therefore, the project will lose the opportunity to receive the transfer of technology and lose the opportunities to experience the train operation and maintenance and may incur more expenses.

\section{SRT's Concessionary}

The administration is quite similar to outsourcing. For outsourcing, SRT must pay the fee to an outside company but in terms of the concession, the concessionaire shall pay the concession fee to the SRT for the amount as stipulated in the contract and condition. The concession fee per year is depending on the agreement. SRT is only responsible for preparing the document and the concession agreement. After the concession contract is signed, the responsibility will be on the concessionaire. SRT only has to oversee the concessionaire to work according to the contract. If the concessionaire has problems such as accessing the construction site or the performance of the concessionaire does not comply with the SRT's stipulation, SRT may help solve the problems similar to hiring an outsource company.
However, transparency and honesty of granting a concession could be low because government personnel may have a conflict of interest of the SARL project. Today, it seems too late for granting a concession for this project because the project has proceeded to the stage of actual operation. The possibility is very little because there are many documents to be prepared and it would take very long time.

\section{Feasibility Study}

California High Speed Rail (CHSRA) is a megaproject, resulting in overly optimistic revenue projections [5]. CHSRA's ridership and revenue projections have been criticized by other agencies, university researchers, and a peer review group. Reviewers have outlined how ridership projections are unrealistically high because they are based on faulty models and flawed $0.0 \quad 0.5 \quad 1.0 \quad 1.5 \quad 2.02 .5 \quad 3.03 .5$ 4.0 4.5 5.0 CHSRA Stated, Not in Business Plan This Report: Optimistic This Report: Pessimistic Considered Unachievable Realistic Travel Time: San Francisco to Los Angeles Blended System: Travel Time in Hours assumptions, mainly about automobile travel costs. This report finds that the CHSRA has made consumer cost assumptions that unrealistically skew the cost of automobile travel to be high. In reality the out-of-pocket automobile costs would be approximately one-third to one-half less than high speed rail fares depending upon distance traveled and how many people are riding in a car. Hence, auto diversion to high speed rail will be lower than projected by the Authority. The Institute of Transportation Studies at the University of California Berkeley found that the CHSRA's ridership forecasts were "not reliable enough to support the expenditure of billions of dollars." It is problems of feasibility study that researcher estimate passenger mostly high than usually case. Which the result of the study will be unreliable when disclosed to the public. The projections are shown in the following figure 1 .

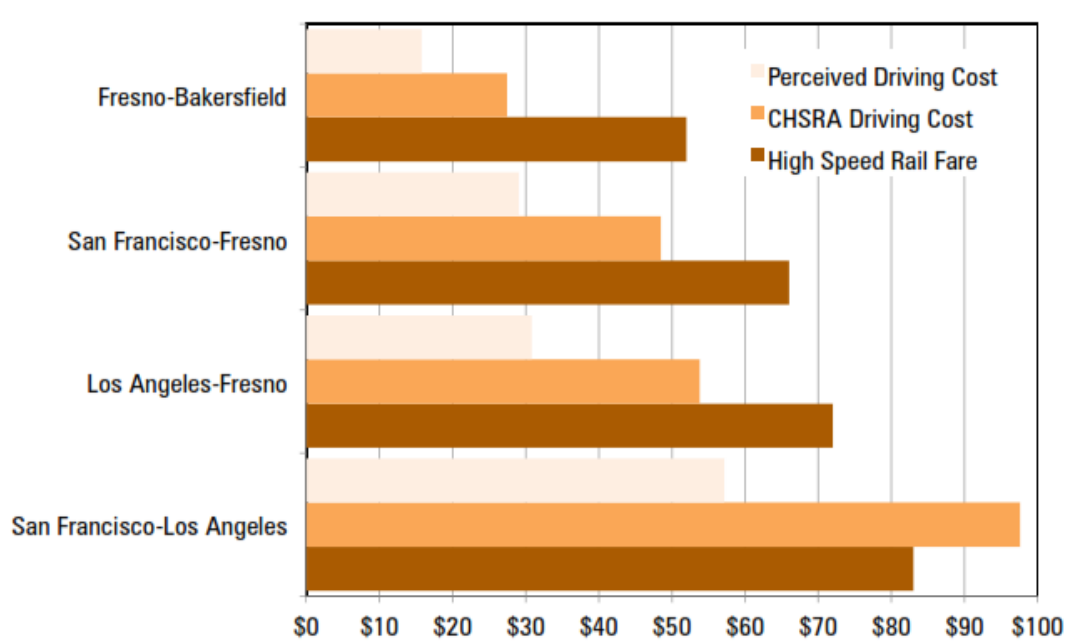

Figure 1. High Speed Rail and Car costs: 2035 (Excludes Parking and Access to and from Stations) [3] 
This report estimates that the cumulative effect of ridership projection irregularities and other factors could be substantial. For example, assuming the optimistic travel time projection of 3:50, the 2035 interregional ridership would be approximately two-thirds (67\%) below CHSRA projected levels at 6.9 million annually. Assuming realistic automobile costs and more-plausible outside-the-corridor ridership, the 2035 interregional ridership would be $77 \%$ below the CHRSA forecast, at 4.8 million annually. Even if the number of automobile drivers switching to rail equals the European experience, ridership would still fall nearly $65 \%$ short of the CHSRA projection

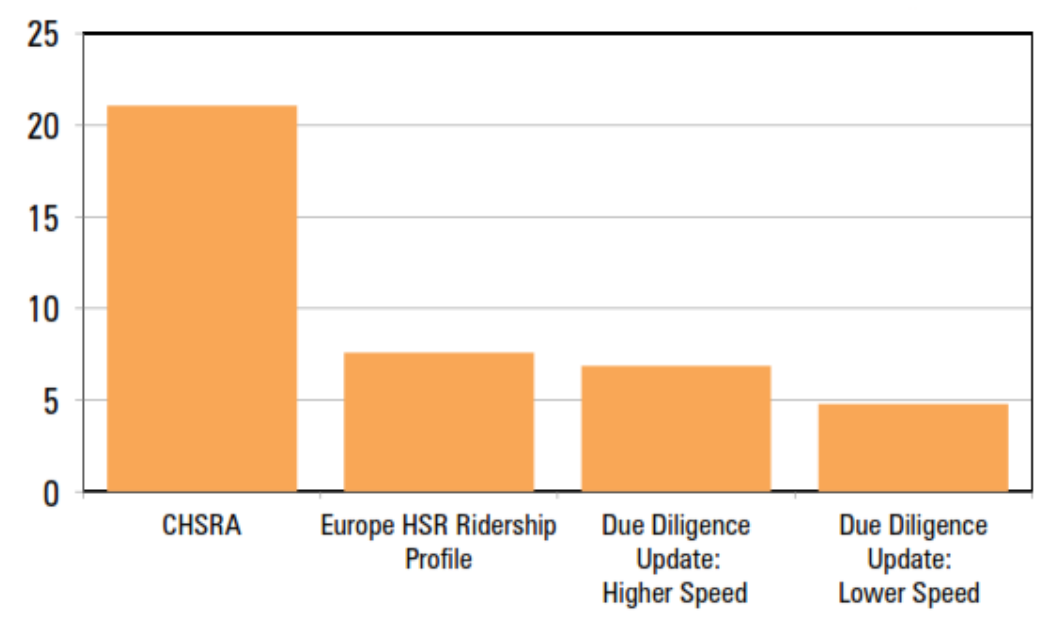

Figure 2. Interregional Ridership Forecasts: 2035 CHSRA and Due Diligence Update (Annual Ridership in Millions) [4]

Additional factors could lead to a larger gap between the forecasts and actual ridership, such as slower population growth and excessive air travel delay bias in forecasts [6]. When all factors are combined, they skew high speed rail ridership much higher than is likely to occur. From the figure 2 was found that the project study is higher than others $2-3$ time which is reading to unreliable report.

\subsection{Data Collection and Analysis}

2.3.1 Due to SARL started the operation since 2010; we collected the past performance and project its return on investment (ROI)which are number of passengers, car parking and rent area, pricing, revenue and expenses, etc.

The process and conceptual framework combined 4 alternatives models, which are business unit, subsidiary, concessionary and outsourcing company. From the 4 proposed models to be verified by the group of railway specialist will be derived 2 models and then compare by feasibility study which can be shown as below picture:

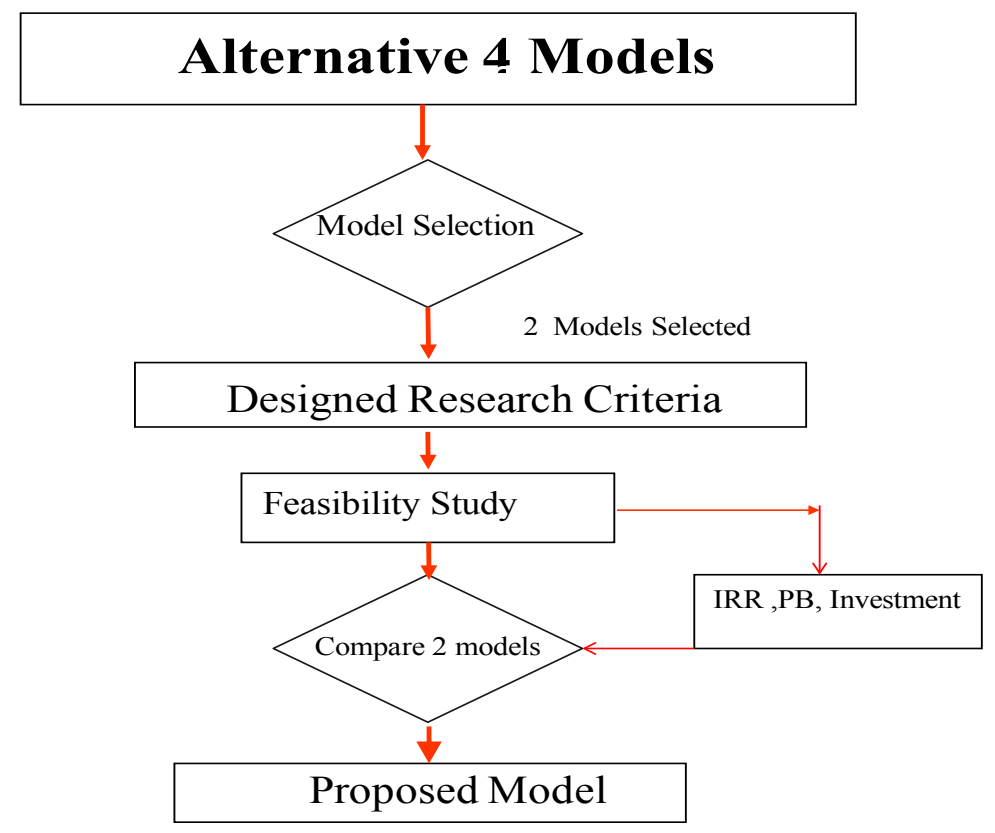

Figure 3. Study Process 
2.3.2 SARL past operation during 2010-2015.

The results of SARL operation under the State Railway of Thailand (SRT) showed that, the gross margin are lost in the beginning of its operation and even they were made gross margin surplus in the year later which is still not enough to absorb other costs which not mention in according to below table:

Table 1. Revenue and Expenses 2010-2015

\begin{tabular}{|c|c|c|c|c|}
\hline \multirow{5}{*}{ Revenue } & Passages & 2010 & 2011 & 2012 \\
\hline & Per hour & 681 & 1,862 & 2,135 \\
\hline & Per day & 12,255 & 33,520 & 38,431 \\
\hline & monthly & $4,472,986$ & $12,234,722$ & $14,027,342$ \\
\hline & Yearly Income & $21,783,075$ & $403,511,104$ & $462,118,788$ \\
\hline \multirow{6}{*}{ Expenses } & Salary & $24,738,081$ & $110,952,324$ & $110,952,324$ \\
\hline & Infra-Structure & $16,888,304$ & $202,659,648$ & $202,659,648$ \\
\hline & Maintenance & $1,089,154$ & $20,175,555$ & $23,105,939$ \\
\hline & Operating & $6,060,500$ & $72,726,000$ & $72,846,000$ \\
\hline & Others & 62,066 & 744,792 & $1,224,792$ \\
\hline & Yearly Expenses & $48,838,105$ & $407,258,319$ & $410,788,703$ \\
\hline \multicolumn{2}{|c|}{ Total(Gross Margin) } & $-27,055,030$ & $-3,747,215$ & $51,330,085$ \\
\hline \multirow{5}{*}{ Revenue } & Passages & 2013 & 2014 & 2015 \\
\hline & Per hour & 2,280 & 2,343 & 2,919 \\
\hline & Per day & 41,032 & 42,170 & 52,542 \\
\hline & monthly & $14,976,573$ & $15,392,224$ & $19,177,791$ \\
\hline & Yearly Income & $489,640,416$ & $504,551,168$ & $627,446,634$ \\
\hline \multirow{6}{*}{ Expenses } & Salary & $121,800,000$ & $121,800,000$ & $121,800,000$ \\
\hline & Infra-Structure & $198,434,488$ & $198,434,488$ & $202,659,648$ \\
\hline & Maintenance & $24,482,021$ & $24,482,021$ & $31,372,332$ \\
\hline & Operating & $72,858,000$ & $72,858,000$ & $72,846,000$ \\
\hline & Others & $1,224,792$ & $1,224,792$ & $1,224,792$ \\
\hline & Yearly Expenses & $418,799,301$ & $418,799,301$ & $429,902,772$ \\
\hline \multicolumn{2}{|c|}{ Total(Gross Margin) } & $-27,055,030$ & $70,741,115$ & $85,751,867$ \\
\hline
\end{tabular}

The other cost which is not revealed in this table is loan repayment; which is interest will be paid more than 240 million Baht per year.

\section{Conclusions}

\subsection{Summary Research}

By the research study process revealed that 4 alternative models and assess by the railway expertise group result that only business unit and subsidiary company which are reliable to be improved the SARL's performance which can be shown as below table:

Table 2. Success factor which can be improved SARL's performance

\begin{tabular}{|c|c|c|c|c|}
\hline & Business Unit & Subsidiary & Outsource & Concessionary \\
\hline Service Readiness & $\checkmark$ & $\checkmark \checkmark$ & $\checkmark$ & $x$ \\
\hline Technology Transfer Knowledge & $\checkmark$ & $\checkmark \checkmark$ & $x$ & $x$ \\
\hline Increased Revenue & $\checkmark$ & $\checkmark \checkmark$ & $x$ & $x$ \\
\hline Financial Risk Reduce & $x$ & $\checkmark$ & $x$ & $\checkmark$ \\
\hline Staff Acceptable & $\checkmark$ & $\checkmark$ & $x$ & $x$ \\
\hline Public Acceptable & $x$ & $\checkmark \checkmark$ & $\checkmark \checkmark$ & $\checkmark \checkmark$ \\
\hline
\end{tabular}

Notes: $\checkmark \checkmark$ : Most possible $\checkmark$ : Possible $\mathbf{x}$ : Impossible 
A paper should have a short, straightforward title directed at general readers in no more than 20 words.

\subsection{Project Feasibility Study}

From the derived 2 model which are business unit and subsidiary deployed under assumption that SARL have to inject at least 8,000 million Baht or about 228.5 million us dollars, loan interest for business unit 3\% as they are under SRT organization which is state-owned enterprise but subsidiary is similar to a private company, the interest will be increased of $6 \%$. The last assumption is source of fund that business unit loan 8000 million from finance institute but subsidiary loan only 4000 million and the rest of 4000 will come from registered capital which is no interest.

Table 3. The project feasibility study of business unit and subsidiary company

\begin{tabular}{ccc}
\hline Case Study & Business Unit & $\begin{array}{c}\text { Subsidiary } \\
\text { Company }\end{array}$ \\
\hline Payback period & $\begin{array}{c}\text { 12 Years and } 4 \\
\text { months }\end{array}$ & $\begin{array}{c}\text { 12 Years and 4 } \\
\text { months }\end{array}$ \\
\hline NPV & $4,441,123,927.52$ & $48,988,187,601.40$ \\
\hline IRR & $23 \%$ & $26 \%$ \\
\hline ROI & $14.59 \%$ & $19.99 \%$ \\
\hline
\end{tabular}

The project study results found that payback period of both model is the same but subsidiary company can earn the return on investment much more that business unit, then the management of SRT have to realize and find the solution for SARL in terms of rules and regulations which may be obstacle in the future improvement.

\subsection{Discussion and Conclusion}

The study also found that executives, both the government and the senior management of the SRT, rarely give precedence to solve problems. Moreover, it also found that the unclear status of whether to establish the company as a subsidiary or a business unit of SRT has caused all employees to lack confidence regarding security and lawful benefits such as salary, welfare, vacation, leave, etc.[9] The government and parties in responsibility should address and solve before they lead to bigger problems. For the development of an alternative business models for Suvarnabhumi Airport Rail Project, there are issues to be discussed as shown below.
Table 4. Issues to be discussed for the development of an alternative business models for Suvarnabhumi Airport Rail Project

\begin{tabular}{cl}
\hline \multicolumn{1}{c}{ Description } & \multicolumn{1}{c}{ Weaknesses } \\
\hline $\begin{array}{c}\text { 1. Number of passengers } \\
\text { and capacity of trains }\end{array}$ & $\begin{array}{l}\text { Limited capacity and insufficient number } \\
\text { of trains. }\end{array}$ \\
\hline 2. Number of passengers & $\begin{array}{l}\text { The number of passengers is more likely } \\
\text { to increase especially during rush hour }\end{array}$ \\
\hline & $\begin{array}{l}\text { Similar to other countries such as } \\
\text { Malaysia, Singapore, Hong Kong, South } \\
\text { Korea. Fares }\end{array}$ \\
\hline 4. Waiting time between \\
trains & $\begin{array}{l}\text { Long waiting time. Crowded and } \\
\text { inconvenient cabin. }\end{array}$ \\
\hline 5. Access to stations. & $\begin{array}{l}\text { Some stations are hard to access because } \\
\text { they are far from the main road. Enter and } \\
\text { exit routes have no lighting, which is risky } \\
\text { and unsafe. }\end{array}$ \\
\hline 6. Service and ticket & $\begin{array}{l}\text { Ticket sales system is inefficient and has } \\
\text { too little officers to serve. }\end{array}$ \\
\hline & $\begin{array}{l}\text { Lacks connection to other mass transit } \\
\text { systems (Bus feeder, Shuttle) and lacks } \\
\text { coordination with other agencies such as } \\
\text { Bangkok Metropolitan Administration, } \\
\text { mass transit systems }\end{array}$ \\
$\begin{array}{l}\text { Tourism Board, aviation businesses, and } \\
\text { tourism association, etc. }\end{array}$ \\
\hline $\begin{array}{l}\text { Train number is not enough. There are } \\
\text { nine trains but only five trains are } \\
\text { operational. The remaining four trains are } \\
\text { not operational because of the lack of } \\
\text { spare parts. There should be an adequate } \\
\text { number of trains in service with one back } \\
\text { up train and one or two back up trains to } \\
\text { support major maintenance after 5 years } \\
\text { of service. }\end{array}$ \\
\hline
\end{tabular}

A subsidiary of the SRT is a format in establishing a company to provide train service and system maintenance service. It was a study to determine the suitable business model to be the practical model for state enterprises in order to administer entities in new ways that granted freedom to the subsidiary in managing its business under the rule of safety in providing train service and vigilant trading principle [11]. The company shall have a management freedom to gain high revenue in order to pay back to the RST, to support financial matters such as payment of employees' pensions, and to be able to enter into the stock exchange [12]. SRT, as the sole shareholder, shall select the CEO and executives in various departments into the company's board of directors. The board of directors shall meet to stipulate plans, policies, and general administrations pertaining to the agenda including issues relating to supervision of safety, providing service to passengers, and spending. 


\section{Acknowledgements}

The researcher would like to thank all the faculty professors that have provided advices and suggestions to make this research more accurate and more complete. I would also like to thank my parents, who have always given me encouragement, as well as the patron of all who were providing me assistances.

\section{REFERENCES}

[1] Office of the National Economic and Social Development Board, The Eleventh National Economic and Social Development Plan (2012-2016), Online available from http://eng.nesdb.go.th

[2] N. Kraiwanit, S. Chaisiripaibool. Credit Scoring Model for Risk Management of Leasing Business in Thailand, Online available from http://www.bus.rmutt.ac.th/journal/pdf/vol7-n o2-03.pdf

[3] U. Amornnimitra. Risk Analysis Technique: A Comparative Study between Logistic Regression Analysis and Discriminate Analysis, Online available from http://www.sci .kmitnb.ac.th/cng_sci/Journal/Journal_2003_1.htm

[4] J. Vranich, W. Cox. California High Speed Rail: An Updated
Due Diligence Report, Reason Foundation, 2008.

[5] Chin-Shan Lu, Pei-Hsuan Chang. Hangbook of Ocean Container Transport Logistics, Springer International Publishing,137-157, 2015.

[6] University of Illinois, et al. Executive report $220 \mathrm{MPH}$ High Speed Rail Preliminary Feasibility Study, Illinois, University, 2013.

[7] A. Black. Urban mass transportation planning. Online available from https://www.planning.org/pas/quicknotes/pdf/QN16.pdf

[8] R. Goodall, W. Kortüm. Active controls in ground transportation: A review of the state-of-the-art and future potential. Vehicle System Dynamics, 12(4-5), 225-257, 1983.

[9] L. J. Goodman, R. N. Love. Project planning and management: an integrated approach, Pergamon Press, 1980.

[10] W. S. Homburger, J. H. Kell. Fundamentals in traffic engineering. Institute of Transportation Studies, University of California, Berkeley, 1992.

[11] A. Marshall. Principles of Economics, 8th ed., London: Macmillan, 1920.

[12] Kasetsart University, Paper presented at the 31st Kasetsart University Annual Conference: Home Economics, Science, Engineering, Agro-Industry, Economics and Business Administration, Education, Humanities, Natural Resources and Environmental Economics, 1993. 